\title{
TRITERPENOIDS AND FATTY ACIDS IDENTIFIED IN THE EDIBLE MUSHROOM Pleurotus sajor-cajú
}

\author{
IVONNE J. NIETO*, CAROLINA CHEGWIN A.
}

Dra. Ivonne Jeannette Nieto, Departamento de Química, Universidad Nacional de Colombia, Sede Bogotá, Ciudad Universitaria, Carrera 30 No. 45-03, Edificio 451 Laboratorio 210. Bogotá-Colombia.

(Received: 9 August 2007 - Accepted: 11 January 2008)

\begin{abstract}
From the ethyl acetate extract obtained from the methanol extract of the mushroom Pleurotus sajor-cajú, ten compounds conforming the triterpenic fraction were isolated by means of chromatographic techniques like CC and PTLC, and were identified by their MS as: Ergosta-2,5,7,9(11),22-pentaene, Ergosta-

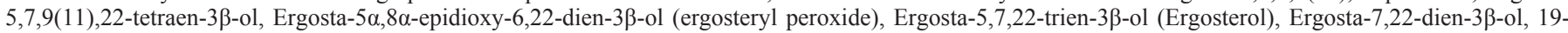
Norergosta-5,7,9,22,tetraen-3 $\beta$-ol (Neoergosterol), Ergosta-7-en-3 $\beta$-ol, Ergosta-3 $\beta$-5 $\alpha, 6 \beta$-trihydroxy-7,22-diene (Cerevisterol), Ergosta-4,6,8(14),22-tetraen-3one and Ergosta-4,6,15(16),22-tetraen-3-one. Likewise, three fatty acids were found and identified as palmitic acid, linoleic acid and stearic acid.
\end{abstract}

Keywords: Fungi, sterols, triterpenoids, fatty acids, Pleurotus sajor-cajú.

\section{INTRODUCTION}

Mushrooms belonging to the Pleurotus genus, more known as oyster mushrooms, alluding to its appearance, have brought great interest due to the versatility of their crop, which contains a wide substrate variety, including agroindustrial waste. However, studies made around its chemical composition have been left aside and are focused in evaluating the optimization of processes involving biomass production. Sajor-cajú species is an edible mushroom of clear colors, saprophyte, primary degrader and wood decomposer from which reports have not been found besides the isolation and quantification of ergosterol $[\mathbf{I V}]^{1}$. About our studies, we present in this article information related to triterpenic composition and the fatty acids identified, and as in Trigos A, we found ergosterol IV accompanied by nine additional triterpenes identified as Ergosta-2,5,7,9(11),22-pentaene I, Ergosta-5,7,9(11),22-tetraen$3 \beta$-ol II, Ergosta- $5 \alpha, 8 \alpha$-epidioxy-6,22-dien-3 $\beta$-ol III, Ergosta-5, 7,22 -trien-3 $\beta$ ol (Ergosterol) IV, Ergosta-7,22-dien-3 $\beta$-ol V, 19-Norergosta-5, 7,9,22, tetraen$3 \beta$-ol VI, Ergosta-7-en-3 $\beta$-ol VII, Ergosta-3 $\beta-5 \alpha, 6 \beta$-trihydroxy-7,22-diene VIII, Ergosta-4,6,8(14),22-tetraen-3-one IX and Ergosta-4,6,15(16),22tetraen-3-one $\mathbf{X}$.

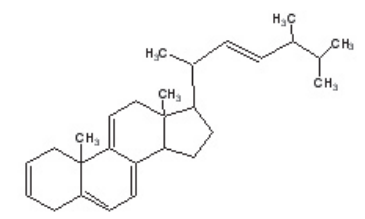

I<smiles>CCC(C)/C=C/[C@H](C)[C@H]1CCC2C3C=CC4CC(C)CC[C@]4(C)C3CC[C@]21C</smiles>

III<smiles>CC1CCC2(C)C(CC=C3C4CCC(C(C)C=CC(C)C(C)C)C4CCC32)C1</smiles>

$\mathrm{v}$<smiles>CC1CCC2(C)C3=CC=C4C5CCC(C(C)C=CC(C)C(C)C)C5CCC4C3(C)CCC2C1</smiles>

II

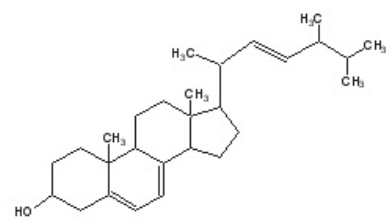

IV<smiles>CC(C)C(C)/C=C/C(C)C1CCC2c3ccc4c(c3CCC21C)CC[C@H](C)C4</smiles>

VI<smiles>CC1CCC2(C)C(CCC3C4CCC5C(C(C)CCC(C)C(C)C)CCC5C4CCC32)C1</smiles>

VII<smiles>CC(C)C(C)/C=C/C1CCC2=C3C=CC4C=CC(=O)CCC4(C)C3CCC21C</smiles>

IX

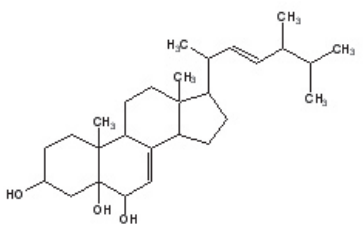

VIII

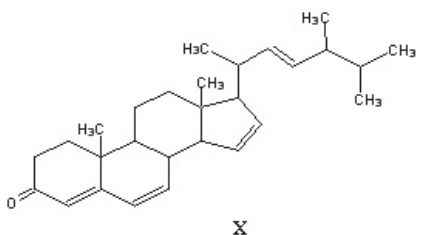

$\mathrm{x}$

\section{EXPERIMENTAL PART}

The mushroom was cultivated over coffee pulp following methodology developed in the Coffee Investigations National Center CENICAFE (Chinchiná Municipality, Caldas-Colombia), using as a total growth criterion the feature of having in the border of the pileus a slight inclination towards the inside. The mushrooms were detached from the substrate, cut in little pieces, dry in oven by convection at $40{ }^{\circ} \mathrm{C}$ and grinded. $164 \mathrm{~g}$ of the grinded material were submitted to extraction with methanol and daily remotion of the solvent concentrating the extract under reduced pressure $(53 \mathrm{~g})$ to be further extracted at $\mathrm{pH} 3$ with ethyl acetate and finally $12 \mathrm{~g}$ were obtained. The components of the extract were separated by $\mathrm{CC}$ in silica gel and using a mixture of toluene and ethyl acetate as eluent starting from toluene only to a ratio of $4: 6$. The triterpenic and particularly steroidal fraction was characterized by GC-MS using a Hewlett Packard 6890 equipment (capillary column HP5, length $30 \mathrm{~m}$, inner diameter $0,33 \mathrm{~mm}$ and thickness $25 \mu \mathrm{m}$, helium as carrier gas, 4,5 at $1 \mathrm{~mL} / \mathrm{min}$ from $90{ }^{\circ} \mathrm{C}$ to $300{ }^{\circ} \mathrm{C}$ at $5{ }^{\circ} \mathrm{C} / \mathrm{min}$ ), coupled to a mass spectrometer 5973 with ion source of $70 \mathrm{eV}$.

\section{RESULTS AND ANALYSIS}

The chromatographic profile of the triterpenic fraction evidenced the presence of 13 compounds; by the cleaving pattern of their mass spectra, three fatty acids commonly distributed inside the fungi kingdom were identified among these compounds: palmitic, linoleic and stearic. As diagnostic peaks, among others, were observed at $\mathrm{m} / \mathrm{z} 60$ the peak corresponding to Mc-Lafferty rearrangement, $\mathrm{m} / \mathrm{z} 73$ (base peak) of $\left(\mathrm{CH}_{2}\right) \mathrm{COOH}^{+}$ion and at $\mathrm{m} / \mathrm{z} 29,43,57$, 71,85 the peaks produced by the consecutive losses of $14 \mathrm{amu}$; their identity was confirmed by comparison with spectra library ${ }^{2}$. The resting compounds (I-X) present the characteristic template of tetracyclic triterpenes, mostly sterols, with structural characteristics that vary in number and position of the unsaturations in the rings and in the side chains, and in the keto and hydroxyl groups located in different positions of the triterpenic template.

Compound I. The mass spectrum presents molecular ion at $\mathrm{m} / \mathrm{z} 376$ 
in accordance with the condensed formula $\mathrm{C}_{28} \mathrm{H}_{40}$. Peaks appear at $\mathrm{m} / \mathrm{z} 361$ $\left(\mathrm{M}^{+}\right.$- methyl), $251\left(\mathrm{M}^{+}\right.$- side chain), $236\left(\mathrm{M}^{+}\right.$- side chain - methyl - H), $225\left(\mathrm{M}^{+}\right.$- fission of D ring in C13 - C17 and C15 - C16), 209 (fission of D ring), 194 (209 - methyl), 156 (fission of C ring) and 141 (156 - methyl). The absence of peaks involving losses of water in their genesis, lead to discard the option of the presence of $-\mathrm{OH}$ groups inside the structure of the molecule. Their fragmentations agree with the ones expected for the triterpene Ergosta2,5,7,9(11),22-pentaene, already isolated in the species ${ }^{3}$.

Compound II. The mass spectrum reveals a $\mathrm{M}^{+}=394$ agreeing with formula $\mathrm{C}_{28} \mathrm{H}_{42} \mathrm{O}$. Peaks are observed at $\mathrm{m} / \mathrm{z} 379\left(\mathrm{M}^{+}\right.$- methyl), $376\left(\mathrm{M}^{+}-\mathrm{H}_{2} \mathrm{O}\right)$, $361\left(\mathrm{M}^{+}\right.$- methyl - $\left.\mathrm{H}_{2} \mathrm{O}\right), 269\left(\mathrm{M}^{+}\right.$- side chain), $251\left(\mathrm{M}^{+}\right.$- side chain - $\left.\mathrm{H}_{2} \mathrm{O}\right)$, 209 (fission of $\mathrm{D}$ ring $-\mathrm{H}_{2} \mathrm{O}$ ), and $141\left(\mathrm{M}^{+}-\mathrm{H}_{2} \mathrm{O}\right.$ - fission of $\mathrm{C}$ ring - methyl), coinciding completely with the expected for a steroidal template type $\Delta^{5,7,9}$ and, different from compound $\mathbf{I}$, presents peaks generated by losses of water, thus allowing to identify it as Ergosta-5,7,9(11),22-tetraen-3 $\beta$-ol that has been already isolated from some species belonging to the kingdom ${ }^{4}$ and specifically in sajor-cajú ${ }^{3}$.

Compound III. This compound presents a MS with a molecular ion of $\mathrm{m} / \mathrm{z}$ $=428$ agreeing with the condensed formula $\mathrm{C}_{28} \mathrm{H}_{44} \mathrm{O}_{3}$. Inside the fragmentation pattern $\mathrm{m} / \mathrm{z} 410\left(\mathrm{M}^{+}-\mathrm{H}_{2} \mathrm{O}\right), 396\left(\mathrm{M}^{+}-\mathrm{O}_{2}\right)$, being the latter characteristic of epidioxy sterols originated presumably by a Retro Diels Alder fragmentation generating a steroidal diene of the type $\Delta^{5,7}$ with its typical fragmentations. Peaks at $\mathrm{m} / \mathrm{z} 253\left(\mathrm{M}^{+}\right.$- side chain $-\mathrm{H}_{2} \mathrm{O}-\mathrm{O}_{2}$ ), 211 (fission of D ring $-\mathrm{H}_{2} \mathrm{O}-\mathrm{O}_{2}$ ) and ion at $\mathrm{m} / \mathrm{z} 337$ generated by an allylic cleavage after the loss of $\mathrm{O}_{2}$, typical of $3-\mathrm{OH} \Delta^{6,7}$ epoxidioxysterols. Based on this features and by comparison with literature ${ }^{5}$, it was found that corresponds to Ergosta- $5 \alpha, 8 \alpha$-epidioxy-6,22-dien$3 \beta$-ol, more known as ergosteryl peroxide, of wide distribution in the kingdom, but still not reported inside Pleurotus genus.

Compound IV. The compound has a molecular weight of 396, according to the mass spectrum and agreeing with condensed formula $\mathrm{C}_{28} \mathrm{H}_{44} \mathrm{O}$. The fragmentation pattern for this molecule is typical of sterols $\Delta^{5,7}$ with ions at $\mathrm{m} / \mathrm{z}$ $381\left(\mathrm{M}^{+}-\mathrm{CH}_{3}\right), 378\left(\mathrm{M}^{+}-\mathrm{H}_{2} \mathrm{O}\right), 363\left(\mathrm{M}^{+}\right.$- methyl - $\left.\mathrm{H}_{2} \mathrm{O}\right), 271\left(\mathrm{M}^{+}\right.$- side chain), $253\left(\mathrm{M}^{+}\right.$- side chain $\left.-\mathrm{H}_{2} \mathrm{O}\right), 211$ (fission of D ring $\left.-\mathrm{H}_{2} \mathrm{O}\right), 143\left(\mathrm{M}^{+}-\mathrm{H}_{2} \mathrm{O}-\right.$ fission C ring - methyl), $337\left(\mathrm{M}^{+}-59\right)$ and 157 being the last two typical for the location of an unsaturation in $\mathrm{C} 22$ of the side chain; agreeing completely with the fragmentation reported in literature ${ }^{4}$ for the compound Ergosta-5,7,22trien-3 $\beta$-ol (Ergosterol), commonly distributed inside fungi kingdom.

Compound V. Molecular ion peak appeared at $\mathrm{m} / \mathrm{z} 398$ agreeing with the condensed formula $\mathrm{C}_{28} \mathrm{H}_{46} \mathrm{O}$. In the mass spectrum the peaks corresponding to the typical fragmentations reported in literature ${ }^{4}$, for the Ergosta-7,22-dien3ß-ol as: $383\left(\mathrm{M}^{+}-\mathrm{CH}_{3}\right), 380\left(\mathrm{M}^{+}-\mathrm{H}_{2} \mathrm{O}\right), 365\left(\mathrm{M}^{+}\right.$- methyl - $\left.\mathrm{H}_{2} \mathrm{O}\right), 337\left(\mathrm{M}^{+}\right.$$59), 300\left(\mathrm{M}^{+}-\mathrm{C}_{7} \mathrm{H}_{14}\right)$ generated for allylic cleavage with hydrogen transference characteristic of unsaturated sterols in $\mathrm{C} 22,273\left(\mathrm{M}^{+}\right.$- side chain), $271\left(\mathrm{M}^{+}\right.$ - side chain - $2 \mathrm{H}), 255\left(\mathrm{M}^{+}\right.$- side chain - $\left.\mathrm{H}_{2} \mathrm{O}\right), 229\left(\mathrm{M}^{+}\right.$- fission of D ring - side chain - $\mathrm{H}$ ) diagnostic for side chain in $\mathrm{C}-17,213$ (fission of $\mathrm{D}$ ring $-\mathrm{H}_{2} \mathrm{O}$ ) and $145\left(\mathrm{M}^{+}-\mathrm{H}_{2} \mathrm{O}\right.$ - fission of $\mathrm{C}$ ring - methyl). In addition, the presence of the peak at $\mathrm{m} / \mathrm{z} 246$ typical of $\Delta^{7}$-3-hydroxyandrostene templates and of peaks at $\mathrm{m} / \mathrm{z} 300,253,229$ and 211 corresponding to unsaturation in C22 confirm the identity of the compound ${ }^{6}$.

Compound VI. The appearance of a molecular ion at $\mathrm{m} / \mathrm{z} 380$ consistent with the condensed formula $\mathrm{C}_{27} \mathrm{H}_{40} \mathrm{O}$ is observed. The characteristic fragmentation pattern of sterols is showed as the one observed for the compounds analyzed above, with the same unsaturated side chain as in C-22 of $\mathbf{V}$ (Scheme 1).

At m/z 347, a low intensity peak appears, corresponding to the loss of $\mathrm{CH}_{3}$ and $\mathrm{H}_{2} \mathrm{O}$, that for a $\Delta^{5,7,9(11)}$ would have a greater intensity, as in the case of ergosterol (I), where this peak corresponds to the base peak, due to the stability of the formed species, where the positive charge, product of the loss of $\mathrm{CH}_{3}$ - 19 , is stabilized by conjugation with the double bonds in C-5 and C-7, and that would lead to propose the absence of the methyl group in C-19 and the presence of an aromatic ring, i.e, a 19-norsterol identified as 19-Norergosta$5,7,9,22$, tetraen-3 $\beta$-ol or Neoergosterol ${ }^{7}$. According to reported on literature, studies have been already made about the possible biosynthetic pathway of this kind of compounds from structurally similar sterols as ergosterol ${ }^{8}$.

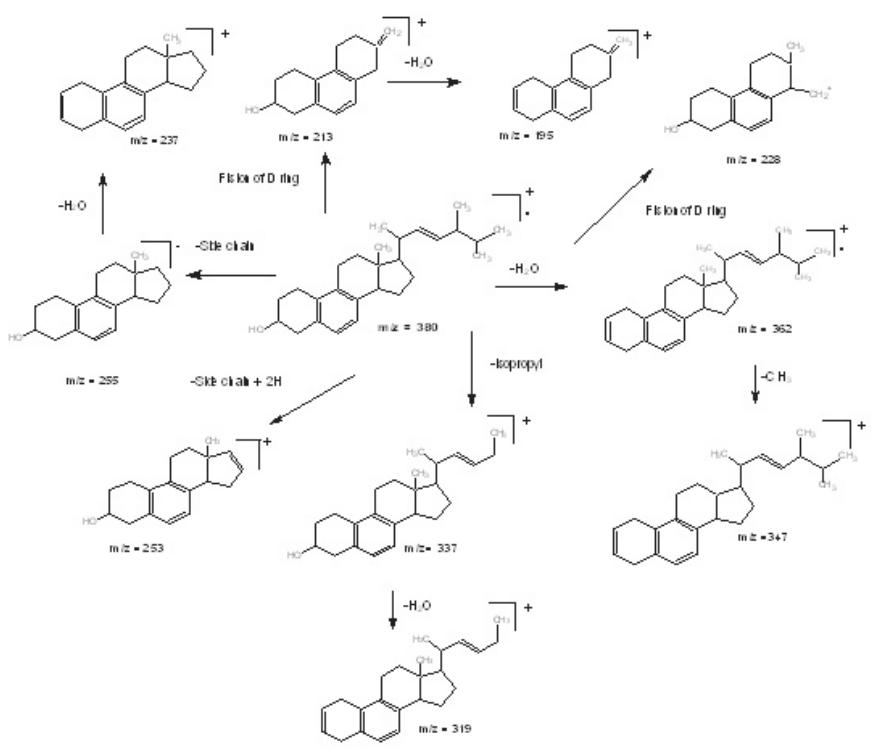

Scheme 1. Fragmentation Diagram for 19-Norergosta-5,7,9,22-tetraen$3 \beta$-ol.

Compound VII. This compound presents $\mathrm{M}^{+}=400$ consistent with condensed formula $\mathrm{C}_{28} \mathrm{H}_{28} \mathrm{O}$ and IHD $=5$ attributed to 4 unsaturations of the rings and a double bond inside the molecule, typical features of sterolic compounds with the peculiarity of having an unsaturation less that compound IV. Fragments at $\mathrm{m} / \mathrm{z} 385\left(\mathrm{M}^{+}\right.$- methyl), $382\left(\mathrm{M}^{+}-\mathrm{H}_{2} \mathrm{O}\right), 367\left(\mathrm{M}^{+}\right.$- methyl - $\left.\mathrm{H}_{2} \mathrm{O}\right), 273\left(\mathrm{M}^{+}\right.$- side chain), $255\left(\mathrm{M}^{+}\right.$- side chain - $\left.\mathrm{H}_{2} \mathrm{O}\right), 246$ (fission of D ring), 231 (246 - methyl), 213 (Fission of $\mathrm{D}$ ring $\left.-\mathrm{H}_{2} \mathrm{O}\right)$ and $145\left(\mathrm{M}^{+}-\mathrm{H}_{2} \mathrm{O}\right.$ - fission of $\mathrm{C}$ ring - methyl), agree with the ones expected for a $\Delta^{76}$ and thus it was identified as Ergosta-7-en-3 $\beta$-ol.

Compound VIII. In the mass spectrum appear peaks which correspond to the typical fragmentations of sterols with a molecular ion at $\mathrm{m} / \mathrm{z} 412$. In the $\mathrm{GC}$ of the terpenoid fraction, the peak corresponding to this compound presents the largest retention time, taking to raise the possibility of having a polyhydroxylated sterol that underwent dehydration and that the peak at $\mathrm{m} / \mathrm{z}$ 412 corresponds to $\mathrm{M}^{+}-\mathrm{H}_{2} \mathrm{O}$ resulting in a real molecular weight of $430 \mathrm{amu}$ whose fragmentations agree with the peaks observed in the MS, as they are: $394\left(\mathrm{M}^{+}-2 \mathrm{H}_{2} \mathrm{O}\right), 379\left(\mathrm{M}^{+}-2 \mathrm{H}_{2} \mathrm{O}-\mathrm{CH}_{3}\right), 287\left(\mathrm{M}^{+}\right.$- side chain - $\left.\mathrm{H}_{2} \mathrm{O}\right), 269\left(\mathrm{M}^{+}\right.$ - side chain $\left.-2 \mathrm{H}_{2} \mathrm{O}\right)$ y $251\left(\mathrm{M}^{+}\right.$- side chain - $\left.3 \mathrm{H}_{2} \mathrm{O}\right)$ (Scheme 2$)$.

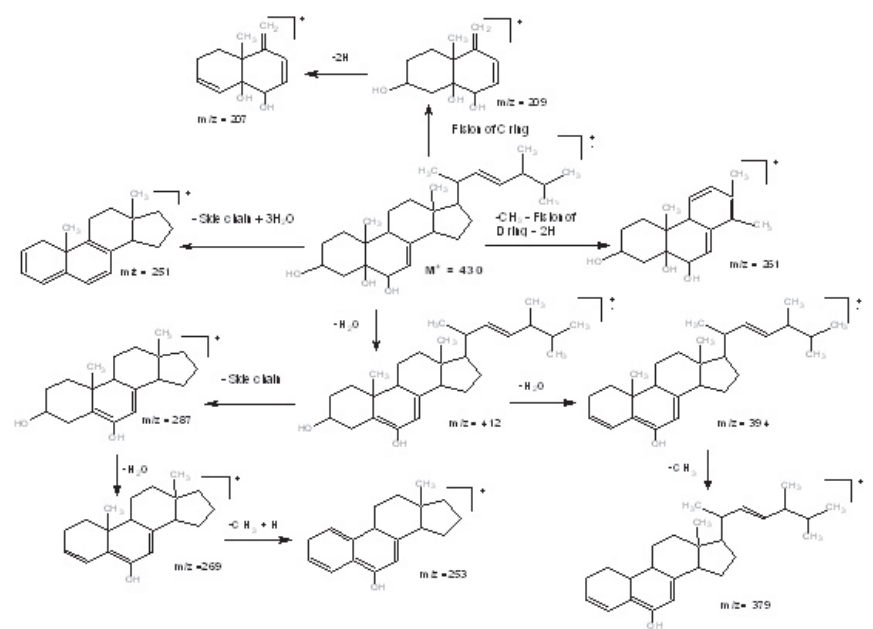

Scheme 2. Diagram of fragmentation of the compound Ergosta-3 $\beta, 5 \alpha, 6 \beta$ trihydroxy-7,22-diene. 
It was determined that this fragmentation pattern is the one corresponding to the compound Ergosta-3 $\beta-5 \alpha, 6 \beta$-trihydroxy-7,22-diene (Cerevisterol), that has been already isolated inside the Pleurotus genus, specifically in $P$. ostreatus $^{9}$.

Compounds IX and X. The mass spectra of these compounds allowed to establish that the substances have the same molecular ion at $\mathrm{m} / \mathrm{z} 392$ consistent with a condensed formula $\mathrm{C}_{28} \mathrm{H}_{40} \mathrm{O}$ and a fragmentation pattern typical of ergostan template. In their mass spectra are commonly observed losses of $\mathrm{CH}_{3}$ $(\mathrm{m} / \mathrm{z}=377)$ and the absence of peaks involving in their genesis losses of water, thus, it is possible that in carbon 3 is a carbonyl group.

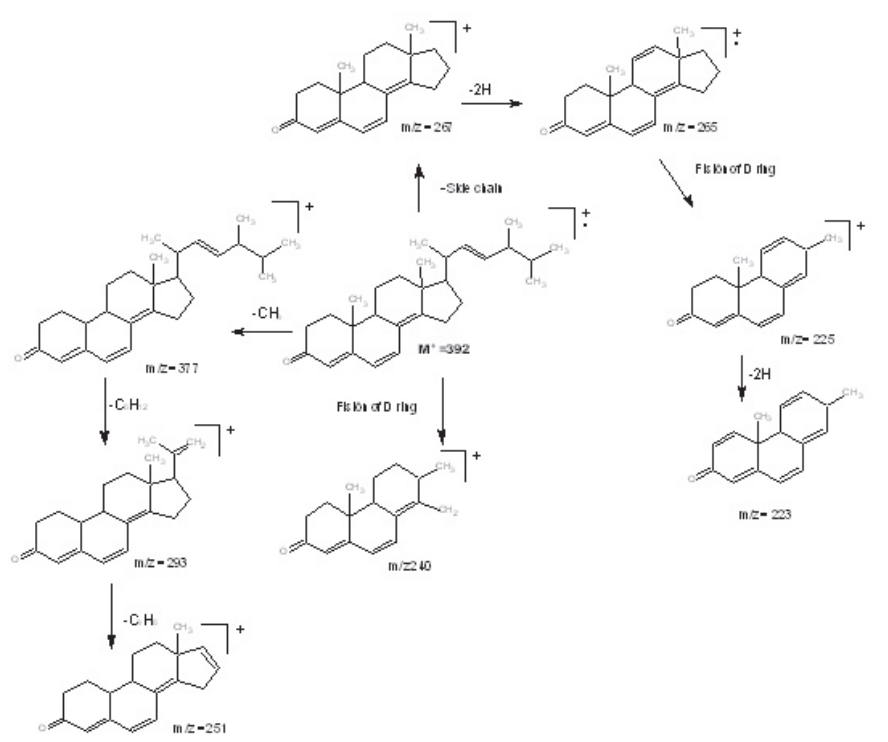

Scheme 3. Diagram of fragmentation of the compound Ergosta4,6,8(14),22-tetraen-3-ona.

Being the base peaks $\mathrm{m} / \mathrm{z} 267$ and 268 respectively, there are peaks appearing due to the loss of the side chain with composition $\mathrm{C}_{9} \mathrm{H}_{17}$. The $1 \mathrm{amu}$ difference between them, is because the migration of one $\mathrm{H}$ of $\mathrm{D}$ ring favored by the presence of a double bond in C15. This hypothesis is confirmed by the analysis of fragmentations typical of this compound identified as Ergosta4,6,15(16),22-tetraen-3-one. The substance IX corresponds to Ergosta4,6,8(14),22-tetraen-3-one, which presents a fragmentation pattern similar to $\mathbf{X}$ confirmed by comparison to reports from literature ${ }^{10}$ and specially because of peak at $\mathrm{m} / \mathrm{z} 240$ generated by fission of $\mathrm{D}$ ring, confirming the position of the double bond between C8 y C12 (Scheme 3).
Compounds III, V, VI, VII, IX and $\mathbf{X}$ have not been isolated inside the Pleurotus genus and therefore this is the first time that their isolation from sajor-cajú species is reported.

\section{ACKNOWLEDGEMENTS}

Authors thank to Chemistry Department and the Division of Research of Bogotá of National University of Colombia.

\section{REFERENCES}

1. A. Trigos, C. Martínez. Hongos comestibles cultivados como fuentes potenciales de ergosterol. Aspectos generales sobre biología de hongos. En Producción de vitamina $\mathrm{D}_{2}$ a partir de hongos macromicetos: aspectos científicos, técnicos y económicos. Editado por Dr. Rivera Umaña A. Colciencias. Bogotá D.C., 1998.

2. MS Chemistation libraries 1995. Hewlett - Packard Wyley library.

3. Osorio, H. Estudio comparativo por CG-EM de las fracciones esterólicas del hongo Pleurotus sajor-cajú cultivado en desechos del café (pulpa, aserrín y su mezcla). Departamento de Química. Universidad Nacional de Colombia.

4. I. Nieto, M. Valencia, Bol. Soc. Chil. Quim. 47, 511, (2002).

5. A. Gunatilaka, Y. Gopichand, F. Shmitz, C. Djerassi, J. Org. Chem. 46, 3860, (1981).

6. D. Itoh, C. Djerassi, J. Chem. Soc. Perkin. Trans. 1, 147, (1985).

7. A. Barrero, E. Oltra, J. Poyatos, D. Jiménez, E. Oliver, J. Nat. Prod. 61, 1491, (1998).

8. A. Barrero, E. Oltra, J. Robinson, P. Burke, D. Jiménez, E. Oliver. Steroids. 67, 403, (2002).

9. Y. Yaoita, K. Amemiya, H. Ohnuma, K. Furumura, A. Masaki, T. Matsuki, M. Kikuchi. Chem. Pharm. Bull. 46, 944, (1998).

10. A. González, J. Bermejo, F. Toledo. Phytochemistry. 22, 1049, (1983). 